\title{
Proximate and mineral composition of some commonly consumed traditional foods/dishes in Nasarawa state, Nigeria
}

\author{
Makanju Dehinde Awogbenja ${ }^{1,{ }^{*}}$, Celestina Adebimpe 0 jo $^{2}$, Winner Paul Shekwonigaza ${ }^{1}$ and Peace Osabo ${ }^{1}$ \\ ${ }^{1}$ Department of Home Science and Management, Faculty of Agriculture, Nasarwa State University, Keffi, Nigeria. \\ ${ }^{2}$ Department of Food Technology and Human Nutrition, University of Agriculture Krakow, Poland
}

International Journal of Biological and Pharmaceutical Sciences Archive, 2021, 02(02), 001-012

Publication history: Received on 18 September 2021; revised on 29 October 2021; accepted on 31 October 2021

Article DOI: https://doi.org/10.53771/ijbpsa.2021.2.2.0083

\begin{abstract}
Traditional foods are recognizable specific cuisine or food peculiar to a particular ethnic group, locality or society. Traditional foods are not only consume for their nutritional values but also for their medicinal and socio-cultural significance. However, information on the nutrient compositions of some of these indigenous dishes are not yet documented. This study is aimed at evaluating the proximate and mineral composition of commonly consumed traditional foods in Nasarawa state Nigeria. A cross sectional survey was adopted and recipes were collected across the ethnic groups for the commonly consumed traditional foods in Nasarawa state. The recipes of ten (10) commonly consumed traditional dishes were standardized in the laboratory, prepared and evaluated for proximate and mineral composition using standard procedures of analyses. The result shows that Moisture content of the foods ranged from 13.39 to $5.78 \mathrm{~g} / 100 \mathrm{~g}$, Crude fibre content was from 19.45 to $2.93 \mathrm{~g} / 100 \mathrm{~g}$, Crude protein ranged from $24.22-5.43 \mathrm{~g}$ /100g, Crude fat 30.32 - 0.92g /100g and Ash 9.84 - 3.82g/100g, Carbohydrate content ranged from 57.31 - $27.17 \mathrm{~g}$ $/ 100 \mathrm{~g}$ and the energy value content ranged from $458.63-326.68 \mathrm{~g} / 100 \mathrm{~g}$. The results of mineral composition further reveal that sodium ranged between 126.00 and $32.00 \mathrm{ppm} / 100 \mathrm{~g}$, potassium between 22.36 and $6.72 \mathrm{ppm} / 100 \mathrm{~g}$, calcium between 2.08 and $0.64 \mathrm{ppm} / 100 \mathrm{~g}$, phosphorus between 2.17 and $0.80 \mathrm{ppm} / 100 \mathrm{~g}$, Magnesium 7.25 and $2.74 \mathrm{ppm} / 100 \mathrm{~g}$ ), while the values for iron, zinc and copper ranged from 4.74 to $2.32 \mathrm{ppm} / 100 \mathrm{~g}, 1.55$ to $0.09 \mathrm{ppm} / 100 \mathrm{~g}$ and 20.49 to $0.17 \mathrm{ppm} / 100 \mathrm{~g}$ respectively. Conclusively, the consumption of these foods will help reduce the high level of non-communicable chronic diseases as they are gotten from natural sources.
\end{abstract}

Keywords: Traditional foods; Mineral composition; Nutrient; fast food

\section{Introduction}

Food is anything which when ingested, digested and assimilated gives energy, replaces worn-out cells, facilitates growth and boost immune system (1). Food provides nutrients, such as protein, carbohydrate, fat, vitamin and minerals used in the body of organism to sustain growth and vital processes such as breathing, digesting of food, keeping warm and for keeping the immune system healthy. Food is one of the basis necessity of life (2). Food is very essential for growth and development. It is necessary for every human to eat on a daily basis. However, cultures and traditions have influence on what we eat. The foods consumed by individual have direct impact on one's ability to enjoy life. (1) defined traditional food as food that are in their original form, not modernized, not processed, not packaged and have a long history of supporting good health, such foods are consumed and are peculiar to a particular group, locality, community or society that have passed through generations.

\footnotetext{
${ }^{*}$ Corresponding author: Makanju Dehinde Awogbenja; E-mail:dendus12@gmail.com

Department of Home Science and Management, Faculty of Agriculture, Nasarwa State University, Keffi, Lafia- ampus, Nigeria 
Traditional foods are a recognizable specific cuisine or food peculiar to a particular ethnic group, locality, community or society (3). Traditional foods can be nutritionally improved by adding the lacking nutrients which are essential for growth and development. These foods consumed by different ethnic groups have been the pride of culinary traditions for centuries (4). Most traditional foods are natural, they therefore are extremely health protective and nutrient rich (5). Traditional foods are not only eaten for their nutritional values but also for their medicinal and socio-cultural significance. Traditional diets are adequate in fibre, magnesium, calcium and potassium but low in protein. Our forefathers lived long on earth due to their dependency on natural forms of food mostly traditional food (6). In the recent times, most of these foods are being replaced by fast foods.

Fast foods are commercial forms of foods sold in restaurants, eateries or store with frozen, preheated or precooked ingredients and served to customers in a packaged form for take-out. Fast foods are also foods that can be prepared and served quickly e.g, noodles, canned fish, canned beans, spaghetti, burger, ice cream etc. Fast foods are high in sodium, saturated fat, trans-fat and cholesterol, they are harmful to health and should not be consumed in large quantity over a long period of time. Too much consumption of fast foods can result in the following health challenges; high blood pressure (hypertension), higher risk of obesity, depression, digestive issues, heart disease, stroke, type 2 diabetes, cancer and early death. For decrease or control of all these health challenges, there is need to abstain from fast foods and return to full consumption of traditional foods. In the recent times, the adverse impact of changed traditional food system is being seriously considered by all those who are socially concerned. The traditional vegetables and food means have become so facile to us during the last four centuries, which means generally, instead of our own food means, we have more attached to the glamour foreign commodities. Therefore, there is a shortage of means of vitamins which were naturally provided to the body through vegetables, green grass, seed and spice materials. This upholds the concern over the changed food system in our society and its impact. There has been a constant effort to gain attention towards changed traditional food system and also the impact of health and social problems caused by it.

Nasarawa state is in the north-central zone of Nigeria with more than 40 tribes of diverse but interwoven cultures and traditions. These people have many indigenous diets prepared with many ingredients in their usual traditional methods. The staple foods of these people are mainly cereal grains, including rice, sorghum, millet, acha and maize; and tubers, including cassava, yam, sweet potatoes and legumes grains. The nutritional value is enhanced through processing into various forms, cooking and then eating varieties of these foods (7). However, information on various nutrient compositions of some of these indigenous dishes are not yet documented. Such information could be used in making nutritional guideline and nutritional education of the people for healthier living. This will help in handling most food related misconception and ailment of these people. This study therefore evaluates the proximate and mineral composition of commonly consumed traditional foods in Nasarawa state, Nigeria.

\section{Material and methods}

\subsection{Study Area}

The study will be conducted in Nasarawa State across ten (10) Local Governments which include Nasarawa, Toto, Awe, Akwanga, Keffi, Karu, Doma, Lafia, Nasarawa Eggon and Wamba. Nasarawa State has an area of 27, 117 km² and a population of 1,869, 377 at the 2006 census. These selected tribes are majorly involved in agricultural practices such as fishing, hunting and farming of Yams, rice, sorghum, millet, melon, groundnut, maize and lot more crops which serves as a source of their income.

\subsection{Study Design}

A cross sectional survey will be adopted for commonly consumed tradition foods for documentation while standardization of the foods recipes will be done by identifying and weighing all the ingredients and food analysis will be carried out in the laboratory.

\subsection{Sample Collection}

All the food ingredients used were bought from Lafia modern market in Nasarawa state.

\subsection{Standardized food}

All the ingredients used for the foods recipe was standardized by weighing the items on a balance (ScoutPro, Ohaus) and the water was measured using graduated cup. The weight of empty pot used was determined using weighing scale (CAMRY Emperor, China) and the yield was also known by weighing the pot and its contents on the weighing scale. 
Table 1 List of traditional foods, ingredients and their methods of preparation

\begin{tabular}{|c|c|c|c|c|c|}
\hline S/No & Tribes & Local Name & Ingredients & Method & English or scientific name \\
\hline 1 & Bassa & $\begin{array}{l}\text { Tiger, tuashenah/ } \\
\text { shepershialubau }\end{array}$ & $\begin{array}{l}\text { Millet flour, locust beans, } \\
\text { dry yam flour, onions, salt, } \\
\text { maggi, pepper, palm oil } \\
\text { and dry fish }\end{array}$ & $\begin{array}{l}\text {-Boil water on medium heat, add pepper, onions, } \\
\text { salt, maggi, dry fish and locust beans, and allow it to } \\
\text { boil for } 10-15 \text { minutes. } \\
\text {-Pound the dry yam into flour and add it into the pot } \\
\text { with continues stirring then allow it to boil for } 2-3 \\
\text { minutes soup is ready. } \\
\text {-Boil water and makes swallow with millet flour and } \\
\text { serve. }\end{array}$ & $\begin{array}{l}\text { Millet (PanicummiliaceumI), locust } \\
\text { beans (parkiabiglobosa), yam } \\
\text { (Dioscoreaalata), onion (Allium } \\
\text { cepa), palm oil (Elaeisguineenis), } \\
\text { pepper (Capsicum spp). }\end{array}$ \\
\hline 2 & Afo & Aapa'aka & $\begin{array}{l}\text { Beans, sorghum, palm oil, } \\
\text { onions, pepper, maggi and } \\
\text { salt. }\end{array}$ & $\begin{array}{l}\text {-Soak the sorghum with little quantity of water and } \\
\text { pound it in a mortar to remove the chaff. } \\
\text {-Pick the beans and mix it with the sorghum and } \\
\text { wash them together. } \\
\text {-Boil water and pour the mixture and add a pinch of } \\
\text { salt, cook it for 4-5 hours under controlled } \\
\text { temperature. } \\
\text {-Bring it down, fry palm oil, onions, pepper, maggi, } \\
\text { and salt and serve together. }\end{array}$ & $\begin{array}{l}\text { Bean (Phaseoluscoccineus), palm } \\
\text { oil (Tlaeisguineensis), } \\
\text { Sorghum (Sorghum bicolor), onion } \\
\text { (Allium cepa), pepper (Capsicum } \\
\text { spp). }\end{array}$ \\
\hline 3 & Gbagyi & $\begin{array}{l}\text { Shnamazhe with } \\
\text { akaygi soup }\end{array}$ & $\begin{array}{l}\text { Yam, processed akagyi } \\
\text { seeds, vegetables, maggi, } \\
\text { salt, dry fish, pepper, } \\
\text { onions and palm oil. }\end{array}$ & $\begin{array}{l}\text {-Boil water, add pepper, salt, onions, maggi, dry fish, } \\
\text { akagyi seed and allow it to boil for } 10-15 \text { minutes } \\
\text { then add vegetable (fluted pumpkin) and stir, then } \\
\text { remove it from heat source immediately. } \\
\text {-Peel yams to desired quantity, wash and boil till soft } \\
\text { then pound and serve with akagyi soup. }\end{array}$ & $\begin{array}{l}\text { Yam (Dioscoreaalata), Fluted } \\
\text { pumpkin (TelfairiaOccidentalis), } \\
\text { African mesquite } \\
\text { (Prosopisaficana), onion (Allium } \\
\text { cepa), palm oil (Elaeisguineenis), } \\
\text { pepper (Capsicum spp). }\end{array}$ \\
\hline 4 & Agatu & $\begin{array}{l}\text { Otutulu with } \\
\text { onagihi }\end{array}$ & $\begin{array}{l}\text { Yam, locust beans, salt, } \\
\text { maggi, dry fish, grinded } \\
\text { dry pepper, onions and } \\
\text { shredded Amplicidaceae } \\
\text { (otutulu). }\end{array}$ & $\begin{array}{l}\text {-Wash and peel the white layer of the Amplicidaceae } \\
\text { stem by scraping the body gently with a knife, peel } \\
\text { the Amplicidaceae into tiny strands and remove the } \\
\text { rope-like layer. } \\
\text {-Discard the hard stick in the middle and wrap the } \\
\text { bunch together, put it in a pot and place it on low } \\
\text { heat for the water to get warm, squeeze the }\end{array}$ & $\begin{array}{l}\text { Yam (Dioscoreaalata), locust } \\
\text { beans (Parkiabiglobosa), pepper } \\
\text { (capsicum spp), Amplicidaceae } \\
\text { (Cissuspopulnea), onion (Allium } \\
\text { cepa) }\end{array}$ \\
\hline
\end{tabular}


International Journal of Biological and Pharmaceutical Sciences Archive, 2021, 02(02), 001-012

\begin{tabular}{|c|c|c|c|c|c|}
\hline & & & & $\begin{array}{l}\text { Amplicidaceaein the pot and remove the strand from } \\
\text { the liquid and set aside. } \\
\text {-Put a separate pot on heat with little quantity of } \\
\text { water, add maggi, salt, dry fish, locust beans and } \\
\text { pepper for } 5-10 \text { minutes. } \\
\text { - bring the liquid set aside from initial and mix } \\
\text { together the bring it down.Soup is ready } \\
\text { - Peel yams to desired quantity, wash and boil till } \\
\text { soft then pound and serve }\end{array}$ & \\
\hline 5 & Mada & $\begin{array}{l}\text { Ngbandar with la- } \\
\text { biku }\end{array}$ & $\begin{array}{l}\text { Bunch of Ngbandar(okra } \\
\text { leaf), groundnut, maggi, } \\
\text { salt, locust beans, potash, } \\
\text { pepper and sorghum flour. }\end{array}$ & $\begin{array}{l}\text {-Wash the bunch of okra leaves thoroughly and put } \\
\text { them in a basket for water to drain. } \\
\text {-Roast the groundnut till brown and peel the back } \\
\text { then pound or grind it and set aside. } \\
\text {-Boil water, add potash, cut the leaves while the } \\
\text { water get boiled, add the leaves and allow for } 3 \text { - } \\
5 \text { munites, add the granted groundnut, salt, maggi, } \\
\text { locust beans, pepper and stir very well. Allow to boil } \\
\text { for } 20 \text { ministes. } \\
\text {-Boil water and make swallow with sorghum flour } \\
\text { then serve. }\end{array}$ & $\begin{array}{l}\text { Okra leaf } \\
\text { (Abelmoschusesculentus), } \\
\text { groundnut (Arachushypogaea), } \\
\text { locust beans (Parkiabiglobosa), } \\
\text { pepper (Capsicum spp), sorghum } \\
\text { (Sorghum bicolor). }\end{array}$ \\
\hline 6 & Koro & Jizzechize & $\begin{array}{l}\text { Millet, palm oil, locust } \\
\text { beans, salt, maggi, pepper, } \\
\text { dry fish, onions and } \\
\text { sesame }\end{array}$ & $\begin{array}{l}\text {-Roast sesame and pound or grind it very well, } \\
\text { sprinkle little water on it. } \\
\text {-Put water on heat and add your locust beans, salt, } \\
\text { maggi, pepper \& dry fish, while the water boils for } \\
20 \text { - } 30 \text { minutes, add the grinded sesame and allow to } \\
\text { boil for } 10 \text { minutes. Add the diced onions and } \\
\text { remove from heat immediately to avoid overdone of } \\
\text { onions. } \\
\text {-Boil water and make swallow with millet flour and } \\
\text { serve. }\end{array}$ & $\begin{array}{l}\text { Millet (Pancummiliaceum) sesame } \\
\text { (sesamumindicum) pepper } \\
\text { (Capsicum spp), onion (Allium } \\
\text { cepa), palm oil (Elaeisguineenis), } \\
\text { locust beans (Parkiabiglobosa). }\end{array}$ \\
\hline 7 & Tiv & Akuye & $\begin{array}{l}\text { Kanaperi (cloves), pepper, } \\
\text { salt, maggi, } r \text { fried } \\
\text { groundnut and sweet } \\
\text { potatos. }\end{array}$ & $\begin{array}{l}\text {-Peel the potatoes and cut into smaller parts, wash } \\
\text { it, boil until it becomes tender. } \\
\text {-Pound all the ingredients together in a mortar. } \\
\text {-Pour the potatoes inside the mortar with the } \\
\text { ingredients, pound together and it is ready. }\end{array}$ & $\begin{array}{l}\text { Sweet potato (Ipomoea btata), } \\
\text { cloves(Eugenia } \\
\text { pepper (Capsicum spp), groundnut } \\
\text { (Arachishypogaea). }\end{array}$ \\
\hline
\end{tabular}


International Journal of Biological and Pharmaceutical Sciences Archive, 2021, 02(02), 001-012

\begin{tabular}{|c|c|c|c|c|c|}
\hline 8 & Gwandara & $\begin{array}{l}\text { Toodunwa with } \\
\text { alaihozana }\end{array}$ & $\begin{array}{l}\text { Water leaves, melon seed, } \\
\text { palm oil, meat, maggi, salt, } \\
\text { pepper, onions and yam. }\end{array}$ & $\begin{array}{l}\text {-Wash the water leaves and cut. Then set aside. - } \\
\text { Grind the melon and set aside. } \\
\text { - parboil the meat and set aside. } \\
\text { - Set a pot on medium heat, fry the oil with onions, } \\
\text { add the melon and fry very well under controlled } \\
\text { temperature, add meat and stock gotten from the } \\
\text { meat, salt, maggi pepper and allow to boil for } 15-20 \\
\text { minutes, add your vegetable and remove from heat } \\
\text { immediately. } \\
\text {-Peel yams to desired quantity, wash and boil till soft } \\
\text { then pound and serve with soup. }\end{array}$ & $\begin{array}{l}\text { Water Leaf (Talinum triangular), } \\
\text { Yam (DioscoreaAlata) White } \\
\text { Melon (Cucumerosismannii) palm } \\
\text { oil (Elaeisguineensis), pepper } \\
\text { (Capsicum spp), and onion (Allium } \\
\text { cepa). }\end{array}$ \\
\hline 9 & Eggon & Omgbogu & $\begin{array}{l}\text { Beans flour, karkashi, } \\
\text { potash, salt, palm oil nylon, } \\
\text { black sesame. }\end{array}$ & $\begin{array}{l}\text {-Grind your beans to powder form, sieve it in a } \\
\text { container, add karkashi and potash to make it soft, } \\
\text { add salt to taste, add water and stir, add little } \\
\text { quantity of palm oil. } \\
\text {-Put it in a nylon to desired size and put it in the pot. } \\
\text {-Put it on heat for } 50-60 \text { minutes. Bring it down, } \\
\text { when ready. } \\
\text {-Roast black beniseed and grand it, pour it into a } \\
\text { deep bowl, add little salt and palm oil to taste and } \\
\text { stir very well. } \\
\text {-Remove omgbo from the black beniseed and serve. }\end{array}$ & 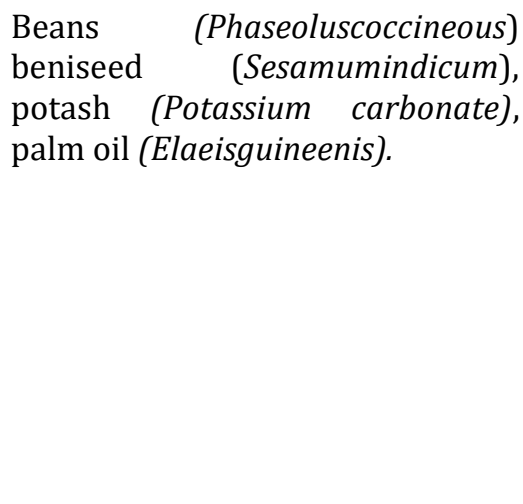 \\
\hline 10 & Buh & Ebuwan & $\begin{array}{l}\text { cannellini beans, white } \\
\text { beniseed, bitter leaf, palm } \\
\text { oil, maggi and salt }\end{array}$ & $\begin{array}{l}\text {-Cook the cannellini beans until it skin start peeling, } \\
\text { add beniseed, add bitter leaf, palm oil, maggi and salt } \\
\text { to taste, allow it on heat for } 20 \text { minutes it is ready. }\end{array}$ & $\begin{array}{l}\text { Beniseed (Sesamumindicum) Palm } \\
\text { oil (Elaeisguineansis) Bitter leaf } \\
\text { (Vernoniaamygdalina), cannellini } \\
\text { beans (Phaseolus vulgaris) }\end{array}$ \\
\hline
\end{tabular}


The recipes collected was standardized using a modified National Food Service Management Institution (NFSMI) (2010) method. According to National Food Service Management Institution, a recipe standardization process can be summarized in three phases: recipe verification, product evaluation and quantity adjustment. In this study, the two major stage of recipe verification phase (recipe review and recipe preparation), was carried out. This was carried out only on one recipe at a time to find out if the recipe contained the following information: (a) recipe title, (b) recipe category, (c) ingredients, (d) weight/ volume for each ingredient, (e) preparation instructions, (f) cooking temperature and time, if accurate, (g) serving size, (h) recipe yield, (i) equipment and utensils used.

\subsection{Sample preparation}

Five grams of each sample was prepared and dried at $100^{\circ} \mathrm{C}$ in an oven until dried, all were crushed separately using a pestle and mortar, and packaged in an air-tight container and stored until ready for nutrient analysis.

\subsection{Nutrient Analysis}

\subsubsection{Proximate Analysis}

Proximate analysis was carried out according to AOAC methods to determine moisture, crude fibre, ash, crude protein, crude fat and carbohydrate.

\subsubsection{Determination of Moisture Contents}

A glass petri-dish was accurately weighed, after which $5.0 \mathrm{~g}$ of the sample was added and reweighed and the weight was recorded as (W1). This was kept in a drying oven for 4 hours at $100^{\circ} \mathrm{C}$ to determine the actual moisture of the standardized foods, the dish was removed from the oven, cooled in a desiccator and re-weighed and was recorded as (W2). This process was repeated until a constant weight is attained. This process was repeated for all the samples, and the moisture content was calculated in percentage as follows:

$$
\% \text { Moisture }=\frac{\text { W1-W2 }}{\text { Weight of sample used }} \times 100
$$

\subsubsection{Determination of Ash Content}

$2.0 \mathrm{~g}$ of sample was accurately weighed in a platinum crucible and was recorded as W1, this was transferred to muffle furnace at the temperature of $550^{\circ} \mathrm{C}$ for 5 hours or until a white ash was obtained. The platinum crucible was removed and place in a dedicator to cool and weighed, this was recorded as W2.

Calculation:

$$
\% \text { Ash }=\frac{\text { W1-W2 }}{\text { Weight of sample used }} \times 100
$$

\subsubsection{Determination of Crude Fibre}

$2.0 \mathrm{~g}$ of standardized food was digested in $200 \mathrm{ml}$ of $1.25 \% \mathrm{H}_{2} \mathrm{SO}_{4}$, the mixture was boiled for 30 minutes on heating mantle, filtered and washed with hot water to reduce the acidity, and this was tested with pH paper indicator. The residue was again transferred and digested in $200 \mathrm{ml}$ of $1.25 \% \mathrm{NaOH}$. The mixture was heated for 30 minutes. Filtered using buncher funnel under pressure and washed with hot water and the filter paper and its content was placed in a drying oven, this was then transferred to a platinum crucible and weighed (W1). The crucible was heated in a muffle furnace at $550^{\circ} \mathrm{C}$ to ash and weighed again as (W2).

Percentage crude fibre is calculated as:

$$
\% \text { Crude fibre }=\frac{\text { w1-w2 }}{\text { Weight of sample used }} X 100
$$

\subsubsection{Determination of Crude Fat}

$2.0 \mathrm{~g}$ of the sample was weighed and placed in a different paper. The filtered paper and its content was transferred in a soxhlet apparatus extractor. The flask was filled with $300 \mathrm{ml}$ petroleum ether $\left(40-60^{\circ} \mathrm{c}\right)$ and allowed to boil. The soxhlet apparatus was allowed to reflux for about 4 hours. The filter paper was removed and the petroleum ether was recovered 
and re-use. When the flask was free of petroleum ether, the flask was removed and dried at $105^{\circ} \mathrm{c}$ for 1 hour. The dried flask was then transferred to a desiccator to cool and weighed.

$$
\% \text { Crude fat }=\frac{\text { Weight of fat }}{\text { Weight of sample }} \times 100
$$

\subsubsection{Determination of Crude Protein}

The protein nitrogen in $0.5 \mathrm{~g}$ of dried samples was converted to ammonium sulphate by digestion with $20 \mathrm{ml}$ of concentrated $\mathrm{H}_{2} \mathrm{SO}_{4}$ and $5 \mathrm{~g}$ of kjehdal catalyst $\left(\mathrm{Cu}_{2} \mathrm{SO}_{4}, \mathrm{~K}_{2} \mathrm{SO}_{4}\right.$ and Selenium dioxide). This was heated on a digestion heater and the ammonia involved was steam distilled into $4 \%$ boric acid solution, the nitrogen from ammonia was deduced from the titration of the trapped ammonia with $0.1 \mathrm{~N} \mathrm{HCl}$ with methyl red and bromocresol green indicator until a green colouration was observed, which indicate the end point of titration. Protein was calculated by multiplying the deduced value of nitrogen by a protein constant $6.25 \mathrm{mg}$.

Percentage Nitrogen

$$
=\frac{(\mathrm{a}-\mathrm{b}) \times 0.01 \times 14 \times V \times 100}{\mathrm{~W} \times \mathrm{C}}
$$

Where:

$\mathrm{a}=$ Titre value of the digested sample

$\mathrm{b}=$ Titre value of blank sample

$\mathrm{v}=$ Volume after dilution $(100 \mathrm{ml})$

$\mathrm{W}=$ Weight of dried sample $(\mathrm{mg})$

C. = Aliquot of the sample used $(5 \mathrm{ml})$

14. $=$ Nitrogen constant in mg.

\subsubsection{Determination of Carbohydrate}

The carbohydrate content of the foods was estimated as the difference obtained after subtracting the values of crude protein, ash content, fat or oil, crude fibre, and moisture content from 100. That is $100-($ protein + ash + oil + crude fibre + moisture content).

\subsection{Energy Consumed}

Energy was calculated from fat, carbohydrate and protein contents using Atwater's conversion factor. Carbohydrate $4 \mathrm{Kcal} / 17 \mathrm{KJ}$, Fat $4 \mathrm{Kcal} / 17 \mathrm{KJ}$ and $9 \mathrm{Kcal} / 37 \mathrm{KJ}$.

\subsection{Mineral Analysis}

The determination of mineral elements was done according to AOAC (2000). 1,0g of each sample was ashed in a muffle furnace at the temperature of $550^{\circ} \mathrm{c}$ and the ashes of various samples was dissolved in $10 \mathrm{ml}$ of $0.1 \mathrm{M} \mathrm{HCl}$, filtered and made up with distilled water to the mark in a $100 \mathrm{ml}$ volumetric flask. The elements to be determined are $\mathrm{P}, \mathrm{Ca}, \mathrm{Na}, \mathrm{K}, \mathrm{Mg}, \mathrm{Zn}, \mathrm{Cu}$, $\mathrm{Fe}, \mathrm{Mn}$ and $\mathrm{Pb}$ using atomic absorption Spectrophotometer (AAS) (AA500 Spectrophotometer, Pg instrument).

\subsection{Statistical Analysis}

The data obtained were subjected to mean and analysis of variance (ANOVA) using IBM SPSS statistics 23 package. Means were separated using Duncan's Multiple Range Test (DMRT). Significance was accepted at $p<0.05$. Values are given as mean \pm S.D. 


\section{Results}

The results of the proximate and mineral composition of commonly consumed traditional foods in Nasarawa State are presented in tables 1 . The result shows that moisture content range from 13.39 to 5.78g/100g. "Tooduwa and aliaho-zana" had the highest moisture content $(13.39 \mathrm{~g} / 100 \mathrm{~g})$ while the least was in "Otutulu with Onagihi" (5.78g/100g). The moisture content in "Tooduwa and aliahozana" and "Otutulu with Onagihi" are significantly different $(\mathrm{P}<0.05)$ compared to the other food samples. "Ebuwan" had the highest crude fibre content $(19.45 \mathrm{~g} / 100 \mathrm{~g})$ and the lowest was in "Mbgawdara with labiku" (2.93g/100g). The crude fibre content in "Ebuwan" and "Mbgawdara with la-biku" are significantly different (P<0.05) from the other foods. The value for the crude protein ranged from $(24.22 \mathrm{~g} / 100 \mathrm{~g})$ in "Shnamazhe with akagyi soup" to (5.43g/100g) in "Ambogu." The values for crude protein are significantly different $(\mathrm{P}<0.05)$. "Tooduwa and alaihozana" had the highest crude fat content $(30.32 \mathrm{~g} / 100 \mathrm{~g})$ and the lowest was in "Mbgawdara with la-biku" $(0.92 \mathrm{~g} / 100 \mathrm{~g})$. The crude fat content in "Tooduwa and alaihozana" and "Mbgawdara with la-biku" is significantly different $(\mathrm{P}<0.05)$. The Ash content ranged from 9.84 to $3.82 \mathrm{~g} / 100 \mathrm{~g}$. "Otutulu with Onagihi" has the highest Ash content $(9.84 \mathrm{~g} / 100 \mathrm{~g})$ while the least was in Aapa'aka" $(3.82 \mathrm{~g} / 100 \mathrm{~g})$. The values for Ash content are significantly different $(\mathrm{P}<0.05)$. Total Carbohydrate content for the traditional foods was found to be $57.31 \mathrm{~g} / 100 \mathrm{~g}$ in "Mbgawdara with la-biku" as the highest while the lowest value was in "Ebuwan" (27.17g/100g). The Energy value content ranged from 458.63 to 326.68g/100g. "Akuye" had the highest Energy content (458.63g/100g) while the least was in "Mbgawdara with la-biku" (326.68g/100g). The values for Energy content are significantly different $(\mathrm{P}<0.05)$.

Table 3 shows the mineral composition of some commonly consumed traditional foods in Nasarawa State. The obtained result for mineral content shows that Sodium (Na) ranged from (126.00ppm/100g) in "Tigar, tuashenah with Shepershi alubau" to (32.00ppm/100g) in "Akuye", the highest occurring in "Tigar, tuashenah with Shepershi alubau" and lowest in "Akuye." Potassium (K) content ranged from (22.36ppm/100g) in "Ebuwan" to (6.72ppm/100g) in "Mbgawdara with labiku." Calcium (Ca) content ranged from 2.08 to $0.64 \mathrm{ppm} / 100 \mathrm{~g}$. "Shnamazhe with akagyi soup" had the highest Calcium content (2.08ppm/100g) while the least was in "Aapa'aka" (0.64ppm/100g). Phosphorus (P) content was higher in "Otutulu with Onagihi" (2.17ppm/100g) while the least was in "Ebuwan" (0.80ppm/100g). Magnesium (Mg) content has the highest value in "Jizze Chize" (7.25ppm/100g) while the least was in "Otutulu with Onagihi" (2.74ppm/100g). Manganese (Mn) has the highest value in "Otutulu with Onagihi" $(0.7310 \mathrm{ppm} / 100 \mathrm{~g})$ and the least in "Mbgawdara with labiku" (0.0640ppm/100g). Iron (Fe) has the highest value content in "Shnamazhe with akagyi" (4.74ppm/100g) while the least was in "Tooduwa with alaihozana" (2.32ppm/100g). Zinc (Zn) has the highest value in "Otutulu with Onagihi" (1.55ppm/100g) while the least was in "Mbgawdara with la-biku" (0.00ppm/100g). Copper (Cu) has the highest value in "Shnamazhe with akagyi soup" (20.49ppm/100g) while the least was in "Tooduwa with alaihozana" (0.17ppm/100g). Lead $(\mathrm{Pb})$ has the highest value in "Aapa'aka" $(0.7150 \mathrm{ppm} / 100 \mathrm{~g})$ while the least was in "Mbgawdara with la-biku" $(0.1100 \mathrm{ppm} / 100 \mathrm{~g})$. There was significant different $(\mathrm{P}<0.05)$ in the values of all the numeral composition.

\section{Discussion}

The proximate compositions of some commonly consumed traditional foods in Nasarawa State were examined in the light of their nutrient contents, calories sources and their contribution to the energy intake. In addition, the mineral compositions of the foods were also examined.

\subsection{The Proximate Compositions}

The evaluation of commonly consumed traditional foods in Nasarawa State revealed high amount of water content with the least moisture content found in "Otutulu with Onagihi" and the highest in "Tooduwa with alaihozana." High moisture content in food indicates a short shelf life due to microbial spoilage. However, low moisture content in any food products means that the food will have more concentrated nutrient and longer storage life.

"Tooduwa and alaihozana" had the highest moisture content 13.39 while the lowest value is seen in "Otutulu with Onagihi" 5.78. The results shows that "Otutulu with Onagihi" have a good storage ability that is to say, it will have a long shelf life among other foods because of its low moisture content. Moisture content influences the taste, texture, weight, appearance and shelf life of the food product. The lower the moisture content of any food products, the more concentrated the nutrient and a long storage life it has (8)

Carbohydrates, most of which come from vegetable foods notably grain products, tubers, roots and fruits are the main sources of energy in foods. The high value for energy level was in "Mbgawdara with la-biku" because of the Sorghum used in the preparation. Carbohydrate is important to the body as a source of fuel that is required to carry out daily activities. 
Table 2 Proximate composition (g/100g) of commonly consumed traditional foods in Nasarawa State

\begin{tabular}{|c|c|c|c|c|c|c|c|}
\hline Food & Moisture & Crude fibre & Crude protein & Crude fat & Ash & Carbohydrate & Energy value \\
\hline Tiger, tuashenah/shepershi alubau & $7.29 \mathrm{bc} \pm 1.29$ & $3.53^{\mathrm{b}} \pm 1.22$ & $16.48^{\mathrm{cd}} \pm 1.48$ & $23.88^{\mathrm{b}} \pm 1.48$ & $6.35^{\mathrm{ab}} \pm 1.29$ & $42.52 \mathrm{a} \pm 1.22$ & $393.61 \mathrm{ab} \pm 83.11$ \\
\hline Aapa'aka & $6.41^{b c} \pm 0.69$ & $3.69^{b} \pm 0.69$ & $19.65^{b c} \pm 0.68$ & $9.62^{\mathrm{d}} \pm 0.68$ & $3.82^{\mathrm{b}} \pm 0.73$ & $56.82^{\mathrm{a}} \pm 0.73$ & $393.50^{\mathrm{ab}} \pm 1.98$ \\
\hline Shnamazhe with akaghi soup & $11.01^{\mathrm{ab} \pm 0.86}$ & $7.25^{\mathrm{b}} \pm 1.01$ & $24.22^{\mathrm{a}} \pm 1.46$ & $15.89^{c} \pm 0.98$ & $8.04^{\mathrm{ab} \pm 0.86}$ & $33.63^{\mathrm{a}} \pm 0.54$ & $374.00^{\mathrm{ab}} \pm 0.35$ \\
\hline Otutulu with Onagihi & $5.78^{c} \pm 0.72$ & $3.71^{\mathrm{b}} \pm 0.69$ & $13.66^{\mathrm{de}} \pm 1.38$ & $23.37^{\mathrm{b}} \pm 1.38$ & $9.84^{\mathrm{a}} \pm 0.72$ & $43.63^{a} \pm 0.69$ & $439.49^{\mathrm{ab}} \pm 9.64$ \\
\hline Mgbawdara with la-biku & $8.81^{\mathrm{abc}} \pm 1.32$ & $2.93_{\mathrm{b}} \pm 0.74$ & $22.29^{\mathrm{ab}} \pm 0.58$ & $0.92^{\mathrm{e}} \pm 0.54$ & $7.73^{\mathrm{ab}} \pm 0.74$ & $57.31^{\mathrm{a} \pm 1.34}$ & $326.68^{\mathrm{b}} \pm 1.78$ \\
\hline Jizze chize & $7.39 \mathrm{bc} \pm 0.71$ & $4.86 \mathrm{~b} \pm 1.46$ & $16.59^{\mathrm{cd}} \pm 1.82$ & $22.57^{\mathrm{b}} \pm 1.78$ & $4.36^{\mathrm{b}} \pm 0.74$ & $44.23^{\mathrm{a}} \pm 1.46$ & $446.43^{a} \pm 14.59$ \\
\hline Akuye & $6.43^{b c} \pm 1.65$ & $3.51^{\mathrm{b}} \pm 1.29$ & $10.52^{\mathrm{ef}} \pm 1.25$ & $23.37^{b} \pm 1.27$ & $4.62^{\mathrm{b}} \pm 1.39$ & $51.56^{\mathrm{a}} \pm 1.57$ & $458.63^{\mathrm{a} \pm 0.17}$ \\
\hline Tooduwa/alaihozon & $13.39^{\mathrm{a}} \pm 1.31$ & $6.40^{\mathrm{b}} \pm 1.07$ & $8.89^{\mathrm{fg}} \pm 0.81$ & $30.32^{\mathrm{a}} \pm 1.43$ & $5.90^{\mathrm{ab}} \pm 1.05$ & $35.11^{\mathrm{a}} \pm 1.43$ & $448.86^{\mathrm{a}} \pm 3.89$ \\
\hline Ambogu & $11.08^{\mathrm{ab}} \pm 1.47$ & $5.69^{\mathrm{b}} \pm 1.01$ & $5.43^{\mathrm{g}} \pm 1.48$ & $8.73^{\mathrm{d} \pm 1.06}$ & $4.45^{\mathrm{b}} \pm 1.53$ & $36.15^{\mathrm{a}} \pm 41.67$ & $358.85^{\mathrm{ab}} \pm 9.09$ \\
\hline Eguwan & $7.63^{c} \pm 1.49$ & $19.45^{\mathrm{a}} \pm 1.70$ & $17.22^{\mathrm{cd}} \pm 1.70$ & $22.12^{\mathrm{b}} \pm 1.36$ & $6.45^{\mathrm{ab}} \pm 1.09$ & $27.17^{\mathrm{a}} \pm 1.39$ & $376.58^{\mathrm{ab}} \pm 12.03$ \\
\hline
\end{tabular}

Table 3 Mineral composition (ppm) of commonly consumed traditional foods in Nasarawa State

\begin{tabular}{|c|c|c|c|c|c|c|c|c|c|c|}
\hline Food & $\mathrm{Na}$ & $\mathbf{K}$ & Ca & $\mathbf{P}$ & Mg & Ma & $\mathbf{F e}$ & Zn & $\mathrm{Cu}$ & $\mathbf{P b}$ \\
\hline $\begin{array}{l}\text { Tiger, } \\
\text { tuashenah/shepershi } \\
\text { alubau }\end{array}$ & $126.00^{a} \pm 2.19$ & $7.73^{f} \pm 0.11$ & $2.53^{\mathrm{b}} \pm 0.31$ & $1.85^{\mathrm{ab}} \pm 1.80$ & $7.19 \mathrm{a} \pm 0.23$ & $0.1935^{c} \pm 0.21$ & $4.24^{\mathrm{cd}} \pm 0.02$ & $0.64^{b c} \pm 0.04$ & $0.25^{\mathrm{de}} \pm 0.07$ & $0.4680^{\mathrm{bcd}} \pm 0.09$ \\
\hline Aapa'aka & $104.50^{\mathrm{b}} \pm 1.12$ & $13.28^{\mathrm{d}} \pm 0.01$ & $0.64^{\mathrm{g}} \pm 0.02$ & $1.06^{b c} \pm 0.99$ & $5.07^{c} \pm 0.12$ & $0.2440^{\mathrm{bc}} \pm 0.23$ & $4.37 \mathrm{bc} \pm 0.05$ & $1.54^{\mathrm{a} \pm 0.05}$ & $0.52^{\mathrm{c}} \pm 0.12$ & $0.7150^{\mathrm{a}} \pm 0.03$ \\
\hline $\begin{array}{ll}\text { Shnamazhe } & \text { with } \\
\text { akagyi soup } & \end{array}$ & $108.56^{\mathrm{b}} \pm 0.98$ & $16.15^{\mathrm{c} \pm 0.21}$ & $2.83^{a} \pm 0.51$ & $2.08^{\mathrm{a}} \pm 2.09$ & $4.81^{\mathrm{cd}} \pm 0.19$ & $0.1500^{\mathrm{cd}} \pm 0.02$ & $4.74^{\mathrm{a}} \pm 0.59$ & $0.11^{\mathrm{ef}} \pm 0.06$ & $20.49^{a} \pm 0.10$ & $0.5780^{\mathrm{abc}} \pm 0.11$ \\
\hline Otutulu with Onagihi & $107.50^{\mathrm{b}} \pm 0.89$ & $10.50 \mathrm{e} \pm 0.04$ & $0.92^{\mathrm{ef}_{ \pm} 0.8}$ & $2.17^{\mathrm{a}} \pm 2.18$ & $2.74^{\mathrm{f}} \pm 0.07$ & $0.7310^{\mathrm{a}} \pm 0.58$ & $4.49^{\mathrm{b}} \pm 0.25$ & $1.55^{\mathrm{a}} \pm 0.09$ & $0.32^{\mathrm{de}} \pm 0.04$ & $0.6140^{\mathrm{ab}} \pm 0.02$ \\
\hline $\begin{array}{l}\text { Mgbawdara with la- } \\
\text { biku }\end{array}$ & $38.50^{\mathrm{e}} \pm 0.98$ & $6.72^{\mathrm{f}} \pm 0.02$ & $0.89 \mathrm{ef}_{ \pm 0.8}$ & $1.25^{\mathrm{abc}} \pm 1.01$ & $4.26^{\mathrm{e}} \pm 0.01$ & $0.0640^{\mathrm{d}} \pm 0.09$ & $3.37^{\mathrm{e}} \pm 0.04$ & $0.00^{f} \pm 0.03$ & $0.30^{\mathrm{de}} \pm 0.02$ & $0.1100^{\mathrm{ab}} \pm 0.09$ \\
\hline Jizze chize & $34.50^{\mathrm{e}} \pm 0.09$ & $12.72^{\mathrm{d}} \pm 0.11$ & $1.81^{\mathrm{c}} \pm 0.18$ & $0.81^{c} \pm 0.18$ & $7.25^{\mathrm{a}} \pm 0.41$ & $0.2050^{c} \pm 0.20$ & $4.25^{\mathrm{cd}} \pm 0.25$ & $0.37 \mathrm{de}^{2} \pm 0.02$ & $0.26^{\mathrm{de}} \pm 0.07$ & $0.3470^{\mathrm{d} \pm 0.02}$ \\
\hline Akuye & $32.00^{\mathrm{e}} \pm 0.03$ & $16.95^{c} \pm 0.23$ & $0.65^{g} \pm 0.05$ & $0.81^{c} \pm 0.11$ & $4.54^{\mathrm{de}} \pm 0.08$ & $0.240^{\mathrm{bc}} \pm 0.19$ & $2.81^{\mathrm{f}} \pm 0.04$ & $0.09^{\mathrm{f}} \pm 0.08$ & $0.44^{\mathrm{cd}} \pm 0.01$ & $0.4990^{\mathrm{bcd}} \pm 0.17$ \\
\hline Tooduwa/alaihozana & $48.00^{\mathrm{d}} \pm 0.79$ & $10.61^{\mathrm{e}} \pm 0.09$ & $0.71^{\mathrm{fg}} \pm 0.01$ & $1.66 \mathrm{abc} \pm 1.20$ & $4.57 \mathrm{de} \pm 0.11$ & $0.0470^{\mathrm{d} \pm 0.08}$ & $2.32^{\mathrm{g}} \pm 0.04$ & $0.18^{\mathrm{ef}} \pm 0.11$ & $0.17 \mathrm{e} \pm 0.02$ & $0.3505^{\mathrm{d}} \pm 0.17$ \\
\hline Ambogu & $33.50^{e} \pm 0.68$ & $17.99^{b} \pm 0.29$ & $0.93^{c} \pm 0.05$ & $0.97^{b c} \pm 0.23$ & $5.93^{b} \pm 0.19$ & $0.3120^{b} \pm 0.25$ & $4.38^{\mathrm{bc}} \pm 0.10$ & $0.50^{\mathrm{cd}} \pm 0.01$ & $2.71^{\mathrm{b}} \pm 0.07$ & $0.4755^{\mathrm{bcd}} \pm 0.01$ \\
\hline Eguwan & $61.50^{c} \pm 1.21$ & $22.36^{\mathrm{a}} \pm 0.41$ & $1.30^{\mathrm{d}} \pm 0.10$ & $0.80^{c} \pm 0.02$ & $7.12^{\mathrm{a}} \pm 0.29$ & $0.2005^{c} \pm 0.15$ & $4.14^{\mathrm{d}} \pm 0.12$ & $0.83^{\mathrm{b}} \pm 0.08$ & $0.61^{c} \pm 0.04$ & $0.4350^{\mathrm{cd}} \pm 0.01$ \\
\hline
\end{tabular}


Low energy food tends to limit total energy intake and the utilization other nutrients. Carbohydrates are the body's preferred source of energy used to support bodily functions and physical activity.

"Otutulu with Onagihi" had the highest value of ash content 9.84 while the least was in "Aapa'aka" 3.82. High control of ash in a food is an indication of increase in minerals content such as Calcium, Potassium, Sodium, Magnesium, Zinc, Iron and Copper (9). Zinc and Iron are trace elements responsible for normal formation or building of bones and strong teeth. Food rich in ash content is recommended for consumption especially for children.

The result obtained from protein has the highest value in "Shnamazhe with akagyi soup" and the least in "Ambogu." Proteins are the building blocks of life. Every human needs protein in diet to help repair body cells and make new ones. They are extremely important during growth, pregnancy and when recovering from wounds. Low protein intake can weaken immune system and excess protein may lead to weight gain and liver problems (1). The daily requirement of protein for toddlers is $13 \mathrm{~g}, 52 \mathrm{~g}$ for men and $46 \mathrm{~g}$ for women. The high protein content in "Shnamazhe and akagyi soup" is as a result of the quantity of dried fish that was used in the food which has $80-85 \%$ high protein.

Fat content has the highest value of $0.9 \mathrm{~g} / 100 \mathrm{~g} 2$ in "Mbgawdara with la-biku" while the highest in $30.32 \mathrm{~g} / 100 \mathrm{~g}$ in "Tooduwa with alaihozana." The functional property of fat is to provide energy and increase the satiety value (7). The body uses fat as a fuel source, and fat is the major storage form of energy in the body. Fat has other important functions in the body, and a moderate amount is needed in the diet for good health. Beef contains saturated and monounsaturated fat, Egusi comprises of $50 \%$ oil because it belongs to the oil seed family with unsaturated fatty acid. These two fat sources "Beef and Melon" gave the high content of fat obtained in "Tooduwa and alaihozana"

Fibre content obtained from "Ebuwan" has the highest value of 19.45 with the least in "Mbgawdara with la-biku" 2.93. The Cannellini bean is the source of high fibre content in "Ebowan" $(6.3 / 100 \mathrm{~g})$. Although crude fibre does not contribute nutrient to the body, it adds bulk to food though facilitating bowel movement and preventing many gastrointestinal disease in both children and adults (10)

The quality of food is determined by energy content present in the foods. The highest energy value content in "Akuye" could be as a result of inclusion of groundnut which is high in fat. The energy value of this food met the recommended value of $400-425 \mathrm{kCal}$.

\subsection{Mineral Composition}

Mineral content of the food samples are relatively good source of minerals. Because they are mostly plant base sources especially the foods containing legumes, nuts and cereal.

The food sample "Otutulu with Onagihi" has the highest content of Phosphorus, Zinc and Manganese, while "Shnamazhe with akagyi soup" has the highest content of Calcium, Iron and Copper. In Sodium, "Tigar,tuashenah with Shiper shialubau" has the highest content, "Ebuwan" has the highest Potassium content, "Jizze Chize" has the highest Magnesium content and "Aapa'aka" has the highest Lead content. Most of these minerals were obtained from the vegetable sources like Pumpkin leaves, Amplicidaceae, Onions and bitter leaf with other sources like Sorghum, Millet and Sesame.

Iron and Zinc are essential in diet for normal growth, hematopoiesis and neurologic development during infancy. These micronutrients are also needed for development and maintenance of the immune system.

Zinc is found in cells throughout the body. It is needed for the body's defensive (immune) system to work properly. It plays a role in cell division, cell growth, wound healing and the breaking down of Carbohydrates. Zinc is also needed for the sense of smell. Iron is an essential element for blood production. It is needed for psychomotor development, maintenance of physical activity and work capacity, resistance to infection. Iron deficiency often leads to anemia, tissue inflammation and fatigue. Iron rich diet helps the respiration process, the transport of oxygen in the blood and in the oxygen generation of red blood cells (10).

Sodium ( $\mathrm{Na}$ ) is used by the body to control blood pressure and blood volume. It also helps the muscles and nerves to work properly. It maintains normal fluid balance. Deficiency in sodium might lead to some health problem, which may prevent the element from performing the function of maintaining acid-base and fluid balances, heartbeat, nerve impulse transmission and cell permeability in the body (11).

Manganese (Mn) is essential in human nutrition; it functions in enzymatic and biochemical reactions in the body. 
Copper $(\mathrm{Cu})$ is an essential trace mineral in human nutrition. Copper aids in the formation of various human tissues and red blood cells. It also works synergistically with zinc and vitamin C. in the formation of skin protein. Though rare in humans, copper deficiency can prevent normal growth and development.

Potassium $(\mathrm{K})$ is necessary for good health and organ function, though most individual's potassium requirements are met by their diet. Food high in Potassium content include dairy, fish, meat, poultry, vegetables, grains, fruits, nuts, potatoes, rice and beans.

Magnesium (Mg) is involved in more biochemical functions than any other mineral in the body. Magnesium is also extremely important in regulating heart rhythms, blood pressure and insulin release (12) Magnesium deficiency can lead to serious health consequences including cardiovascular disease and reduction in cell formation the dietary allowance of magnesium in adult is $0.35-0.45 \mathrm{ppm}$ per day.

Calcium is the most abundant mineral in the body. It makes up 1.5-2\% of our body weight, with bones making up about $99 \%$ of the body's Calcium content. Calcium builds and maintains healthy bones and teeth. It is also involved in much of the body's enzyme activity as well as regulation of cardiovascular functions. Calcium deficiency can lead to rickets and growth retardation in children. In adults, calcium deficiency can lead to osteoporosis, poor bone density, muscle spasms, leg cramps and cardiovascular irregularities (10). Every individual is recommended to consume about $1000 \mathrm{mg}$ of calcium daily.

\section{Conclusion}

This study has also shown that the traditional foods which are less expensive and are mostly natural source base could be consumed to ensure good health and reduce the risk of non-communicable chronic disease. These foods are nutrient rich although most of the foods were moderately rich in minerals they could be consumed and use to replaced fast foods to ensure a healthy living. Most, traditional food are low in protein and micronutrients sources that are required by the body for effective functioning and therefore, should be standardized to make sure it meet the individual dietary requirement to ensure adequate growth and development thereby preventing malnutrition. The findings of this study provide information on the proximate and mineral composition of some traditional foods in Nasarawa State which could contribute to nutrient data bank in Nigeria food composition.

\section{Compliance with ethical standards}

\section{Acknowledgments}

The author wish to appreciate the support of the Prof O.J Jayeoba and Mr. O.J Rotowa of Nasarawa State University and University of Agriculture in Krakow respectively for their contribution to see that this manuscript comes to a success

\section{Disclosure of conflict of interest}

The authors hereby declares that there's no conflict of interest and that we all agreed that the paper be published.

\section{References}

[1] Amadi, BA, Ayalogu, EO and Onyeike, EN Nutrient and antinutrient composition of "Onunu" and "Mgbam", traditional foods of Ikwerre ethnic nationality in South - South, Nigeria. JETEAS2 2011; (3): 551 - 555.

[2] Okaka, JC. and Okaka, ANC. Foods: Composition spoilage and shelf - life extension. $1^{\text {st }}$ edn. Ocjanco publishers, Enugu. 2001; Pg 1 - 2.

[3] Kyle, R. and Cole, E. Classification of food, in: Food and Nutrition, $2^{\text {nd }}$ edition, Bruce and world Inc. New York. 2001; pp. 21 - 29.

[4] Achi 0. K. (2005). The upgrading of traditional fermented foods through biotechnology. African Journal of Biotechnology, 4:375-380

[5] Amadi, BA, DuruMajesty, KC and Agomuo, EA Nutrient composition of "Nduduagworagwo", A traditional food of Akokwa people in Ideato North LGA of Imo state, Nigeria. 2012; 6 (3): 27 - 32.

[6] Trichopolou, A., Soukara, S and Vasilopou. Iou. E. Traditional foods: A science and society perspective. Trends in food science and technology 2007; 18:420-427. 
[7] Awogbenja, MD. and Ugwuona, FU. nutrient and phytochemical composition of some commonly consumed Traditional Dishes in Nasarawa State, Nigeria. 2012; 8 (1): 30 - 39.

[8] Zakpea, HD Al-Hassan, A., Adubofour,J. An investigation into the feasibility of production and characterization of starch from 'apantu' plantain (gaint horn) grown in Ghana. African Journal of Food Science; 2010; 4(9):571-577.

[9] FAO/WHO (1991). Vitamin and mineral requirements in human nutrition, 2nd ed. Geneva, World Health Organization, 1991.

[10] Levetin-McMahon Plants as a source of food- Human Nutrition. $5^{\text {th }}$ (ed), The MeGraw Hill companies, 2008; pp. $160-161$.

[11] Satyanarayana, U and Chakrapani, U, Essential Biochemistry $2^{\text {nd }}$ edition, Book and Allied (P) Ltd. Beliaghata Main Road, Kolkata, India, 2009; 210-224.

[12] Umar, KJ Hassan, LG and Garba HJ. Proximate and mineral composition of M. miristica. Chemclass Journal 2005; 3: 81-84. 